https://doi.org/10.18485/iipe_postsovjet.2021.ch15

\author{
Вељко Благојевић \\ Игор Пејић ${ }^{1}$
}

\title{
Грузија као потенцијални „тројански коњ“ Запада на Кавказу
}

\begin{abstract}
Ancmpaкm: Након слома Совјетског Савеза, Кавказ се показао као регион који је подложан верским и етничким конфликтима. Бивше совјетске републике су на различите начине покушавале да пронађу одговарајући „фактор стабилности“ који би решио унутрашња безбедносна питања и избалансирао односе са моћним суседом, Руском Федерацијом, као потенцијалном претњом по новостечену независност. Грузија је након „револуције ружа“, покушала да своју спољну политику преоријентише ка Западу и тиме „осигура своју сувереност“ над отцепљеним територијама Јужне Осетије и Абхазије. Мала држава на Кавказу, попут Грузије, тежила је да „уновчи“ свој геополитики положај тиме што би западним силама пружила олакшан приступ руској зони интереса у Кавкаском региону (Near Abroad или Ближнее зарубежье), и на овај начин поврати отцепљене територије под своју контролу. Сукоб 2008. године и војна интервенција Русије показале су да је регион Кавказа и даље „неприступачан“ за Запад који нема јасну представу о култури, традицији и политичко-безбедносној ситуацији и односу снага у региону. Недавни конфликт у Нагорно-Карабаху потврдио је неприступачност Запада овом региону, али и указао на значај Кавказа у регионалном концепту равнотеже снага у коме доминирају Руска Федерација и Турска. Рад ће се фокусирати на положај Грузије у региону Кавказа и њене односе са Русијом и западним силама. Анализом грузијске
\end{abstract}

\footnotetext{
${ }^{1}$ Вељко Благојевић, научни сарадник у Институту за стратегијска истраживања. veljko_blagojevic_55@hotmail.com.

Игор Пејић, истраживач приправник у Институту за стратегијска истраживања. amon.sum@gmail.com.
} 
спољне политике у геополитичком контексту, показаћемо значај „малих“ актера за регионалну равнотежу снага и последице неконзистентне и стратегијски недовољно рационалне политике, која не узима у обзир геостратешко окружење у коме би требало да се реализује.

Кључне речи: Грузија, Руска Федерација, Запад, Кавказ, Нагорно-Карабах.

\section{Уводна разматрања}

Урушавање совјетске империје обележило је крај једне епохе међународне политике. Биполарни систем, који је трајао скоро пола века, изненада је окончан радикалним мерама новог комунистичког руководства које је покушало да ревитализује државу и прилагоди је „новом светском поретку“. Политичка и економска криза која је уследила, осим што је показала све мањкавости комуниситчког система, такође је отпочела процес дезинтеграције совјетског простора.

Настанак нових држава на бившем совјетском простору створило је могућности за нова геополитичка „маневрисања“ како регионалних тако и светских играча. Формулисањем концепта блиског суседства (Near Abroad) тадашњи министар спољних послова Руске Федерације, Јевгениј Примаков, покушао је да постсовјетски простор дефинише у погледу зоне искључиво руског интереса. Геополитичка оправданост овог концепта почива првенствено на војним дефанзивним плановима, чиме би се задржала тзв. бафер зона према осталим актерима Евроазије. Иако се овај концепт одржао као релативно успешна замисао тадашњег руског руководства, такође је наишао на многобројне проблеме који су уследили као непосредна последица распада Совјетског Савеза и наглог опадања моћи руске државе на крају 20. века. Губитак контроле на Кавказу оживео је старе сукобе утемељене не етничким и верским поделама тамошњег становништва. Сукоби у Нагорно-Карабаху, а затим у Чеченији, показали су да је интеграција ових региона у једну целину, као што је био Совјетски Савез, представљала привремено решење. ${ }^{2}$

Ратови у Чеченији на крају 20. и почетком 21. века представљали су озбиљну претњу која је имала потенцијал да дестабилизује како регион

\footnotetext{
${ }^{2}$ Сукоби у Молдавији и у Таџикистану такође су обележили распада Совјетског Савеза.
} 
Закавказја тако и остатак Русије. Страх од ових ратова, као и озбиљност претњи, потврђују и изјаве руског председника у којима се истиче да је проблем Чеченије могао да доведе до тзв. „југославизације“ читаве државе. ${ }^{3}$ У том периоду проблем исламистичког тероризма задобио је међународну димензију. Њему су објавиле један вид „рата“ готово све државе света, који су предводиле САД. Упркос основаној потреби да се заштити државна територија и становништво у Чеченији, начин на који се Русија обрачунавала са побуњеницима изазвао је критике на Западу. Наиме, борба руских оружаних снага са Чеченима тумачена је на Западу као политичко а не безбедносно питање Москве. Оштар став Русије према сепаратистима након доласка Путина, окаратерисан је као покушај којим се побуђује нови руски национализам, а који има за циљ легитимизацију сличне политике према осталим бившим совјетским републикама. ${ }^{4}$

Етничко-верски сукоби након распада Совјетског Савеза обновљени су и у јужном делу Закавказја између Јерменије и Азербејџана. За Јермене Нагорно-Карабах је регион од виталног интереса, при чему подршка Руске Федерације Јеревану у овом сукобу представља важан аспект јерменске тврде моћи. ${ }^{5}$ С друге стране, Русија такође пружа „дипломатску“ подршку Азербејџану истичући важност територијалног интегритета и целовитости државне територије у међународној политици. Одмерени приступ Русије према сукобљеним странама показује значај овог конфликта за руску регионалну политику, али такође открива зазирање Русије у погледу једностраног решења конфликта у Нагорно-Карабаху.

Обазривост Москве произилази из значаја Азербејџана за америчку спољну политику у Евроазији. Значај ове државе огледа се у њеној прозападној спољнополитичкој оријентацији, неблагонаклоном ставу према Москви, као и њеном географском положају који јој омогућава

\footnotetext{
${ }^{3}$ Fiona Hill, "The Real Reason Putin Supports Asad", Foreign Affairs, March 2013.

${ }^{4}$ Peter W. Rodman, "The Challangers of a Falling power", in: Robert Kagan and William Kristol (eds.), Present Dangers: Crisis and Opportunity in American Foreign and Defense Policy, Encounter Books, San Francisco, 2000, p. 95.

5 Јерменија је више пута током година истицала сарадњу са Русијом као главни аспект спољне политике и разлог због чега држава не тежи НАТО или европским интеграцијама. (Tracey German, "The Nagorno-Karabakh Conflict between Azerbaijan and Armenia: Security Issues in the Caucasus", Journal of Muslim Minority Affairs, Vol. 32, Issue 2, 2012, p. 221).
} 
директан приступ каспијским изворима енергената. Успостављањем добрих односа са Азербејџаном, Запад је увидео могућност обуздавања даљег руског утицаја на Кавказу. ${ }^{6}$ Једнострана подршка Јерменији у том контексту додатно би отежала односе Русије и Азербејџана. Следећи реалистичку матрицу међународних односа Русија има интерес да одржи конфликт „на танком леду“ чиме би удаљила обе државе од западних партнера, док би, с друге стране, додатно обезбедила стратешко партнерство са Јерменијом. ${ }^{7}$ Штавише, неуспели преговори током претходне две деценије указују да Русија није имала приоритетан интерес да се упостави јединствено решење које је прихватљиво за обе стране или није поседовала капацитете регионалног хегемона да то постигне. Из тог разлога одмерен приступ према Јерменији и Азербејџану, при чему ниједна држава не може да буде сигурна да је конфликт у НагорноКарабаху решен, помаже Москви да одржи утицај на овом простору и регионалну равнотежу снага која њој одговара.

Опасност по руске интересе задобило је нову димензију када су поједине државе, попут Украјине и Грузије, исказале своје прозападне аспирације. Иако је тешко говорити да западне силе могу угрозити Русију, као што је то био случај током 19. и 20. века, губитак контроле над постсовјетским простором постао је реалан ризик на почетку овог века. Експанзија НАТО на исток из тог разлога је перципирана као једна од главних претњи за руску спољну политику и концепт мултиполарног света у коме би Русија била једна од великих сила. ${ }^{8}$

Током деведесетих година 20. века грузијска власт, на челу са председником Шеварнадзеом, релативно успешно је балансирала између националистичких тежњи домаћег становништва и руских интереса који су ову државу посматрали као део шире руске регионалне хегемоније. ${ }^{9}$

\footnotetext{
${ }^{6}$ Миломир Степић, Геополитика: Идеје, теорије, концепције, Институт за политичке студије, Beograd, 2016, стр. 478, 500.

${ }^{7}$ Kavus Abushov, "Russian foreign policy towards the Nagorno-Karabakh conflict: prudent geopolitics, incapacity or identity?", East European Politics, Vol. 35, Issue 1, 2019, pp. 4-6.

${ }^{8}$ Bobo Lo, Russian Foreign Policy in the Post-Soviet Era Reality, Illusion and Mythmaking, Palgrave Macmillan, UK, 2002, pp. 132-134.

9 Thornike Gordadze, "Georgian-Russian Relations in the 1990s", in: The Guns of August: Russias War in Georgia (eds.) Svante E. Cornell and S. Frederik Starr, M. E. Sharpe, New York, 2009. pp. 28-49.
} 
Односи двеју држава почели су да се компликују непосредно пре „револуције ружа“ када је руководство Грузије изразило захтев за уклањање руских база са државне територије, док је Москва, с друге стране, почела да шаље војну помоћ становништву на територијама Јужне Осетије и Абхазије. ${ }^{10}$ Са доласком председника Сакашвилија реформе које је нова власт предузела биле су усмерне, између осталог, и на питање територијалног интегритета. Региони Абхазије и Јужне Осетије брзо су постали главна тачка сукоба између Москве и Тбилисија. Талас "демократије“ који се ширио након револуције омогућио је новом грузијском руководству да побољша имиџ на Западу и јасно оријентише правац спољнополитичког деловања. Подршку коју је изразио тадашњи амерички председник Џорџ Волкер Буш, описујући Грузију као „светионик демократије“ у региону, показала је да Запад види могућност успеха тзв. обојених револуција, што је такође пружило додатну наду да Грузија може у једном тренутку да приступи евроатлантским структурама. ${ }^{11}$

Августовски рат 2008. године представљао је реакцију Русије на покушај Грузије да војним средствима поврати контролу над отцепљеним територијама, али и могуће геополитичке процесе у њеном блиском суседству које би водиле ка даљим променама у регионалној равнотежи снага. Иако није најпрецизније представити овај сукоб као класично уравнотежавање моћи глобалне униполарне силе, с обзиром на одсуство западних сила овом сукобу као и њихов уздржан став по питању деловања Грузије, циљ руске интервенције свакако је био усмерен на очување равнотеже снага која одговара интересима Москве.

\section{Августовски рат и спољна политика Грузије}

Евроатлантске интеграције, које је пропагирала Сакашвилијева влада, представљају дискутабилно стратешко опредељење државе која је у

\footnotetext{
${ }^{10}$ Andrei Illarionov, "The Russian Leadership's Preparation for War, 1999-2008", in: The Guns of August: Russias War in Georgia (eds.) Svante E. Cornell and S. Frederik Starr, M. E. Sharpe, New York, 2009, pp. 54-56.

${ }^{11}$ Niklas Nilsson, "Georgia's Rose Revolution: The Break with the Past", in: The Guns of August: Russias War in Georgia (eds.) Svante E. Cornell and S. Frederik Starr, M. E. Sharpe, New York, 2009, pp. 98-101.
} 
непосредној близини регионалне силе која такву политику перципира као угрожавање виталних интереса у региону. Сакашвилијеве погрешне процене у вези западне подршке на коју Грузија може да рачуна у случају сукоба са Русијом, увеле су ову државу у рат са противником који је то иначе очекивао. ${ }^{12}$ Брзо распоређивање људства и ратне технике уочи конфликта говоре у прилог томе да је Москва имала планове у случају рата са Грузијом. Руске оружане снаге у годинама пре избијања сукоба усвојиле су оперативне планове који се тичу оружаних дејства у области Кавказа, што се првенствено могло уочити у јачању капацитета Севернокавкаског војног округа. ${ }^{13}$ О чињеници да се Русија припремала за сукоб са Грузијом говоре и изјаве Медведева, у којима тадашњи председник Федерације истиче да би изостанком интервенције у Грузији Русија ризиковала да остале суседне државе покушају исту политику прикључења западним безбедносним структурама, као и да је сама интервенција због тога представљала „васпитно средство“ за остале актере у региону. ${ }^{14}$

Прозападни вектори грузијске спољне политике били су уочљиви и деведесетих година прошлог века када је ова држава приступила Северноатлантском савету за сарадњу и Евроатлантском савету за партнерство. ${ }^{15}$ Након скупа у Букурешту 2008. године, када су Западни савезници изјавили да Грузија може да постане пуноправан члан НАTO, убрзале су се руске сумње да Грузија као бивша совјетска република представља озбиљну претњу која може да наруши регионални геополитички концепт. Војна интервенција, која је уследила исте године, имала је за циљ сузбијање даљих прозападних аспирација Грузије.

12 Michael Kofman, The August War, Ten Years On: A Retrospective On The Russo-Georgian War, War on the Rocks, August 2018, https://warontherocks.com/2018/08/the-augustwar-ten-years-on-a-retrospective-on-the-russo-georgian-war/, 04/03/2021; Драган Петровић, Драгомир Анђелковић, Горан Николић, Геополитика Закавказја, Институт за међународну политику и привреду, Београд, 2010, стр. 256-264.

${ }^{13}$ Carolina Vendil Pallin \& Fredrik Westerlund, "Russia's war in Georgia: lessons and consequences", Small Wars \& Insurgencies, 2009, Vol. 20, Issue 2, pp. 404-407.

${ }^{14}$ Ryan Desseyn and Lasha Tchantouridzé, "Realpolitik And The Russia-Georgia War: Three Years On", Central Asia And The Caucasus, Vol. 13, Issue 1, 2012, p. 112.

${ }^{15}$ NATO, Relations with Georgia, https://www.nato.int/cps/en/natohq/topics_38988.htm, 04/03/2021. 
Одсуство помоћи западних актера у августовском рату, као и промене у америчкој администрацији 2008. године, негативно су се одразиле на односе између САД и Грузије. Наиме, Обамини напори да се изврши тзв. „ресет“ са Русијом указали су на умањивање геостратешког значаја Грузије за западне силе. Промене на изборима у Грузији 2012. године такође су наговестиле да ново руководство државе жели нормализацију односа са Русијом, што би се лоше одразило на западне интересе и потенцијално удаљило Грузију од евроатлантских интеграција. ${ }^{16}$

Спољнополитичка опредељења Грузије према западним силама и НАТО нису се променила након августовског рата, већ је њихова сарадња добила нове форме после 2009. године. Формирањем Комисије НАТОГрузија, која функционише у оквиру Годишњег националног програма, омогућава грузијским властима да спроведу реформе у сектору безбедности уз подршку и препоруке НАТО савезника. Штавише, формирањем овог тела грузијска влада одређује приоритете и коригује своју економску, безбедносну, војну и законодавну политику у складу са препорукама западних држава. Кључни аспект ове сарадње јесу реформе у сектору безбедности и имплементација НАТО стандарда грузијском сектору безбедности и оружаним снагама. Коначни циљ ове сарадње је ефикасно спровођење реформи у држави и њена припрема за прикључење евроатлантским интеграционим процесима, за шта власт иначе има подршку јавног мњења. ${ }^{17}$

Упркос овим дешавањима Грузија је и након 2008. године одржала прозападни правац спољне политике. Наиме, 2010. године у Грузији је отворена НАТО канцеларија за заједничко деловање, чија је основна мисија побољшавање практичне сарадње између Грузије и НАТО, као и прикључење ове државе Алијанси. ${ }^{18}$ Спремност Тблисија да учествује у

\footnotetext{
${ }^{16}$ Franziska Smolnik, "The Strategic Partnership between Georgia and the United States: Vision Wanted", German Institute for International and Security Affairs, SWP Research Paper, 15 December 2020, Berlin, pp. 11-12.

${ }^{17}$ NATO Backgrounder, Deepening Relations with Georgia, https://www.nato.int/nato static/assets/pdf/pdf_publications/deepening_relations_with_georgia_en.pdf, 15/03/ 2021.

18 Канцеларија НАТО у Грузији https://www.nato.int/cps/en/natohq/topics_81066.htm? selectedLocale=en, 11/03/2021.
} 
мировним операцијама предвођене западним силама била је очигледна, како пре тако и после „револуције ружа“. Наиме, у циљу јачања сарадње са Западом Грузија је ангажовала већи број припадника оружаних снага у Ираку, око 3.000 војника, током интервенције коалиције предвођене САД. У Авганистану Грузија је такође активно учествовала у пружању подршке мисији за очување безбедности (ISAF). Иако је ова мисија окончана 2014. године, Грузија је наставила да одржава присуство оружаних снага (ОС) у Авганистану са око 800 војника. ${ }^{19}$

Одржавање заједничких војних вежби са западним силама, као и отварање различитих центара за обуку и едукацију припадника грузијских оружаних снага у протеклих неколико година, указује на интензивирање војне сарадње Грузије и НАТО. Центар за тренинг и евалуацију формиран је 2015. године под покровитељством НАТО, с циљем обуке, едукације и побољшања оперативних способности грузијске војске у складу са западним стандардима. Осим овог центра, НАТО је такође основао школу за изградњу одбрамбених институција (Defense Institution Building School), у циљу даље професионализације грузијских OC. ${ }^{20}$ Надаље, војне вежбе такође представљају важан аспект прозападне политике Грузије. Почев од 2011. године у Грузији се одржава мултинационална војна вежба „Agile Spirit" у којој учествују ОС држава евроатлантског савеза, чији је циљ јачање оперативних способности ОС у оквирима конвенционалног рата. ${ }^{21}$ Друга редовна годишња војна вежба коју Грузија организује на својој територији, заједно са НАТО савезницима, је „Noble Partner" која се први пут одржала 2015. године. Главни циљ ове вежбе, слично као и код претходне, јесте јачање оперативних способности грузијских снага у

${ }^{19}$ Anders Wivel, "Living on the edge: Georgian foreign policy between the West and the rest", Third World Thematics: A TWQ Journal, Vol. 1, Issue 1, 2016, p. 102; Грузија je тренутно ангажовала 860 војника у контингенту мисије "Resolute Support" у Авганистану, што потврђује констатну у спољнополитичком опредељењу Грузије. https://www.nato.int/nato_static_fl2014/assets/pdf/2020/6/pdf/2020-06-RSMPlacemat.pdf, 15/03/2021.

${ }^{20}$ Cory Welt, Georgia: Background and U.S. Policy, Congresional Research Service, p. 11, https://fas.org/sgp/crs/row/R45307.pdf, 21/03/2021.

${ }^{21}$ Agile Spirit 2019: exercise to host over 3,000 NATO and partner troops in Georgia, Agenda.Ge, https://agenda.ge/en/news/2019/391, 17/03/2021. 
реалним условима и побољшавање капацитета оружаних снага САД за деловање у мултинационалном окружењу. ${ }^{22}$

Прозападну оријентацију грузијске политике потврђују и донације које ова држава добија од САД. У периоду од 2010. до 2019. године Грузија је у оквиру различитих фондова и програма америчке власти, који се тичу обуке и снабдевања оружаних снага других држава, добила донације у вредности од 265 милиона долара. Вашингтон је од 2010. године такође пружао и финансијску помоћ намењену реформама у цивилном сектору, у просеку од око 65 милиона долара годишње. ${ }^{23}$ Због свега наведеног, Грузија себе доживљава као стратешки чвор (strategic hub) за амерички спољнополитички и економски продор ка централној Азији. Током посете америчког државног секретара 2019. године, премијер Грузије истакао је значај стратешког партнерства двеју земаља и посведочио значај своје државе за америчке интересе на простору Кавказа и централне Азије. За Америку, по мишљењу премијера Бакхтадзеа, Грузија пружа јединствен приступ унутрашњости азијског континента, као и бољи приступ азијском тржишту. ${ }^{24}$ Наиме, продубљивањем економске сарадње Грузија се нада чвршћем партнерству са Америком које ће обухватити и друге секторе државне политке, попут војног и безбедносног. Пројекат изградње луке у Анаклији, на обали Црног мора, требао је да обезбеди Грузији лакши приступ светској трговини у погледу логистичког центра путем којег би се трговина одвијала даље ка унутрашњости Азије. Иако је пројекат представљан као економски, позиција ове луке, као и могућност приступа пловила ратне морнарице са дубоким газом, имплицира да овај пројекат може да има и војно-стратешки значај. Сједињене Државе, које су иначе биле заинтересоване за изградњу луке, одустале су од реализације овог

${ }^{22}$ Exercise Noble Partner 2020 begins, US Embassy in Georgia, https://ge.usembassy.gov/ exercise-noble-partner-2020-begins/\#: :text=Exercise\%20Noble\%20Partner\%20is\%20 designed,exercises\%2C\%20and\%20combined\%20mechanized\%20maneuvers, 17/03/2021; Noble Partner Military Exercise in Georgia, Caspian Policy, https:// www.caspianpolicy.org/nato-exercises-in-georgia/, 17/03/2021.

${ }^{23}$ Cory Welt, Georgia: Background and U.S. Policy, Congresional Research Service, pp. 1820, https://fas.org/sgp/crs/row/R45307.pdf, 21/03/2021.

${ }^{24}$ US Embassy in Georgia, https://ge.usembassy.gov/statements-to-the-press-withgeorgian-prime-minister-mamuka-bakhtadze-as-part-of-the-u-s-georgia-strategicpartnership-commission-june-11/, 18/03/2021. 
пројекта. Бројни унутрашњи проблеми са којима се суочавају грузијске власти, а који се првенствено тичу корупције, утицале су на овакаву одлуку Вашингтона. ${ }^{25}$ Јасно је да ово није једини разлог одустајања САД од наведеног пројекта, већ процена да би изградња луке коштала много више од потенцијалних добитака. Надаље, изградња луке би додатно иритирала руску страну да предузима контрамере које би превасходно биле усмерене према Грузији, коју Сједињене Државе сматрају за регионални ослонац своје спољне политике.

Спољнополитички напори грузијских власти да се приближе западним центрима моћи, иако представљају потенцијалну претњу за руске интересе на Кавказу, суштински не могу да наруше регионалну равнотежу снага. Време је показало да је политика Грузије према евроатлантским интеграцијама умногоме једнострана инцијатива ове државе, при чему Тблиси већ годинама покушава да докаже значај и оправда потенцијал свог геостратешког положаја у односу на Русију. Интереси Сједињених Држава у овом делу Евроазије, који подразумевају одржавање стабилности и промоцију демократије, не представљају виталне интересе глобалне силе. ${ }^{26}$ За Европу, такође, Грузија не представља јасно одређену државу која би прикључивањем допринела европској заједници и њеним интересима на Кавказу, нити према Русији. Држава која себе доживљава као део европске породице, сматрајући да Грузија може премостити разлике између азијског и европског дела Евроазијског континента, не уклапа се у безбедносни концепт Брисела. Наиме, за Европску унију случај Грузије представља незгодан проблем који додатно компликује европске напоре да балансира између сопствених демократских идеала и партнерства са Русијом које је неизбежно. ${ }^{27}$

${ }^{25}$ John C. K. Daly, Russia's Discreet Satisfaction Over Georgia's Anaklia Port Debacle, Jamestown, https://jamestown.org/program/russias-discreet-satisfaction-over-georgiasanaklia-port-debacle/, 18/03/2021.

${ }^{26}$ Eugene Rumer, Richard Sokolsky, Paul Stronski, U.S. Policy Toward the South Caucasus: Take Three, Carnegie Endowment for International Peace, https://carnegieendow ment.org/2017/05/31/u.s.-policy-toward-south-caucasus-take-three-pub-70122, 18/02/2021.

${ }^{27}$ Anders Wivel, "Living on the edge: Georgian foreign policy between the West and the rest", Third World Thematics: A TWQ Journal, Vol. 1, Issue 1, 2016, p. 100. 
Упркос овим стратешким препрекама, идеја да Грузија може да постане „тројански коњ“ Запада на Каваказу и даље је присутна код државног руководства. Побољшавање руско-грузијских билатералних односа, након укидања ембарга на грузијске производе 2013. године, слабо је утицало на промену перцепције Русије код домаћег становништва. ${ }^{28}$ Историја Русије као велике силе која полаже право на регион Кавказа свакако утиче на овакву перцепцију, али указује и на недостатак меке моћи руске спољне политике. Наиме, иако Европа не жели да своје односе са Русијом доведе у питање због Грузије, успостављање ЕУ мониторинг мисије у Грузији, након 2008. године, указује на њено веће присуство у овом региону. ${ }^{29}$ Изјава бившег потпредседника САД да ће „Америка бити ту за Грузију док не уђе у НАTO", током посете овој држави 2017. године, такође показује да Вашингтон није одустао од овог региона. ${ }^{30}$ Штавише, током година Грузија је имала низ активности које указују да концепт евроатлантских интеграција и даље представља окосницу њене спољне политике. Изјава Генералног сектретара НАТО, Јенса Столтенберга, да Алијанса остаје посвећена концепту јачања безбедности у региону Црног мора, као и да сарадња са Украјином и Грузијом представља значајан аспект ове политике, потврђује наставак политике отворених врата Алијансе и интеграцију бивших совјетских република. ${ }^{31}$ Упркос пандемији корона вируса мултинационална војна вежба „Noble Partner 2020“ одржана је у Грузији, при чему је фокус био на јачању безбедности и оперативних способности оружаних снага у региону Црног мора. ${ }^{32}$ На крају, треба напоменути и да поједини медији и

${ }^{28}$ NDI, NDI Poll: EU and NATO Support Remains Strong but Threatened by Russia and Perception of Harm to Culture and Values; Armenian and Azeri Communities Respond Differently to NATO Membership, https://www.ndi.org/publications/ndi-poll-eu-andnato-support-remains-strong-threatened-russia-and-perception-harm, 13/03/2021.

${ }^{29}$ Philip Remler, Russia's Stony Path in the South Caucasus, Carnegie Endowment for International Peace, https://carnegieendowment.org/2020/10/20/russia-s-stony-pathin-south-caucasus-pub-82993, 11/03/2021.

${ }^{30}$ Robert E. Hamilton, "August 2008 and Everything after: A Ten-Year Retrospective on Russia-Georgian War", Foreign Policy Research Institute, October 2018, p. 26.

${ }^{31}$ Agenda.Ge, NATO announces deepening partnership with Georgia, Ukraine, https://agenda.ge/en/news/2020/1028, 27/03/2021.

${ }^{32}$ Deutche Welle, Georgia launches joint military drills with NATO countries, https://www.dw.com/en/georgia-launches-joint-military-drills-with-nato-countries/a$54846498,27 / 03 / 2021$. 
think-tank пласирају концепт у коме Грузија треба и може да постане равноправан члан НАТО. ${ }^{33}$ Атлантски савет (Atlantic Council) у том погледу предлаже да интеграција Грузије у НАТО може да се изврши упркос нерешеним територијалним питањима. Наиме, два региона која су од 2008. године фактички под руском управом, не морају да представљају проблем ако се „модификују“ чланови 5 и 6 Повеље НАТО. ${ }^{34}$ Иако, су шансе за овако нешто релативно мале, чињеница да овакве идеје постоје указују на то да западне силе нису изгубиле из вида регион Кавказа, као и да им је јасно шта представљају главне полуге моћи Русије на овом простору.

\section{Сукоб у Нагорно-Карабаху и регионална равнотежа снага}

Напетости између Азербејџана и Јерменије око провинције НагорноКарабах јављају се од касних 1980-их година. На том простору већину становништва чине Јермени. Сукоб је избио када су јерменски посланици 1988. године у Националном одбору Нагорно- Карабаха гласали за уједињење са Јерменијом. Борбе у Нагорно-Карабаху ескалирале су након што су Јерменија и Азербејџан добили независност. Јерменско становништво насељено у Нагорно-Карабаху одржало је референдум у децембру 1991. године, након чега је проглашена независност и оснивање Републике Нагорно-Карабах, која није међународно призната. Пошто ранији совјетски предлог, који је предвиђао већу аутономију за НагорноКарабах унутар Азербејџана, није био задовољавајући за обе стране, избио је рат између Јерменије и Азербејџана. У оружаном сукобу 1992. и 1993. године Јерменија је поразила Азербејџан и ставила под контролу НагорноКарабах, и 20\% околне територије која је до 2020. године била под ефективном влашћу јерменских снага. Споразум о прекиду ватре постигнут je у мају 1994. године под окриљем тзв. Минск групе ОЕБС-а. ${ }^{35}$ у

\footnotetext{
${ }^{33}$ Visegrad Insight, A Staunch Ally, https://visegradinsight.eu/staunch-ally-georgia-nato/, 24/03/2021.

${ }^{34}$ Atlantic Council, End the Russian veto on Georgian accession, https://www.atlantic council.org/content-series/nato20-2020/end-the-russian-veto-on-georgian-accession/, 24/03/2021.

35 Групу чине: Јерменија, Азербејџан, Чешка, Француска, Немачка, Италија,Русија, Шведска, Турска и САД.
} 
спорадичним оружаним инцидентима, који су се периодично догађали и поред потписаног споразума о примирју, погинуло је више од 35 хиљада лица док је милион становника расељено са конфликтног подручја. ${ }^{36}$

У спољнополитичком наступу Азербејџана од стицања независности примењују се два принципа. Први је принцип реципроцитета, док се други узима као примарни. Реч је о односу међународних актера према Јерменији и ставовима према конфликту у Нагорно-Карабаху. Овај принцип је умногоме усложњавао приступ Русије према Ајзеберџану, јер је реч о највећем спољнотрговинском партнеру Русије на Кавказу и државама које располажу знатним количинама природног гаса. Истовремено, Русија настоји да Азербејџан држи што даље могуће од утицаја Запада, што је њен стратегијски циљ. Истовремено са настојањима да задржи избалансирани приступ, Русија је настојала да посредује између Азербејџана и Јерменије за решавање сукоба у Нагорно-Карабаху. Током председничког мандата Дмитрија Медведева (2008-2012), Русија је покренула мировну иницијативу за решавање спора Јерменије и Азербејџана, уз подршку Сједињених Држава и Француске. У оквиру иницијативе, Медведев је такође подржао јачање сарадње Јерменије и Турске, најближег савезника Азербејџана. Међутим, до тога није дошло због противљења јавног мњења обе стране. На крају је руска иницијатива доживела неуспех. ${ }^{37}$

Русија је у спољнополитичком наступу настојала да, подржавајући Јерменију, покуша да избегне усложњавање односа са Азербејџаном. До 2010. године Русија је била дискретна у погледу продаје оружја Јерменији како би избегла провоцирање Азербејџана, негирајући извештаје о великом трансферу наоружања који су се периодично јављали, укључујући и оне из 2009. године, као и током недавног пораста борби. Русија је почела да продаје све софистицираније наоружање на обе

\footnotetext{
36 За више видети: Thomas de Waal, The Caucasus - An Introduction, Oxford University Press, 2010, pp. 94-130; Ana Jović Lazić, Sanja Jelisavac Trošić, Aleksandar Jazić, „Problem Nagorno Karabah u svetlu bilateralnih odnosa članica Minsk grupe OEBS-a“, Međunarodni problemi, Vol. LXIII, br. 4, str. 584

${ }^{37}$ Philip Remler, Russia's Stony Path in the South Caucasus, Carnegie Endowment for International Peace, October 20, 2020, https://carnegieendowment.org/ 2020/10/20/ russia-s-stony-path-in-south-caucasus-pub-82993, 18/02/2021.
} 
стране и била је отворенија према његовом балансирању. Примера ради, Русија је 2010. године потписала нови закуп своје војне базе у Гјумрију ${ }^{38}$ (продуживши уговор до 2044. године) и пристала да прода Азербејџану противваздухопловни ракетни систем земља-ваздух С-300. ${ }^{39}$

Четвородневни рат између Јерменије и Азербејџана 2016. године, представљао је најкрвавији сукоб две земље од прекида ватре 1994. године. Азербејџанске снаге су успеле да ставе под своју контролу неколико значајних стратешких позиција у зони сукоба. Поново се као медијатор за прекид сукоба појавила Русија, која је настојала да буде непристрасана. То је, с једне стране, иритирало Јермене као најпоузданије руске савезнике у региону а, с дуге стране, појачало сумњичавост Азербејџана. Предлог за распоређивање руских мировних снага још једанпут није прихваћен. Ова кратка војна операција је само потврдила чињеницу да је конфликт у Нагорно-Карабаху све само не замрзнут. ${ }^{40}$

Сведоци смо да у време пандемије корона вируса није било значајнијих оружаних сукоба, јер је тежиште ангажовања кључних ресурса система безбедности већине држава ангажовано на обезбеђење здравља нација. Изузетак у том погледу представља оружани сукоб у НагорноКарабаху који је започео дејствима азербејџанских оружаних снага 27. септембра 2020. године. Поред специфичности стратешког избора времена почетка војних операција, Азербејџан се определио и за тежишну примену савремених средстава ратне технике. Реч је о наоружаним беспилотним летилицама, набављеним из Турске и Израела, које су наносиле велике губитке јерменским снагама. Јерменија не располаже наведеним наоружањем, што се показало као озбиљан стратешки недостатак, који је кључно определио исход ратног сукоба. Нема никакве сумње да се Азербејџан дужи низ година спремао за

\footnotetext{
${ }^{38}$ Руско-јерменски односи се често сматрају стратешким савезом. За Јерменију је то свакако тачно, јер 3.000 руских војника са седиштем у другом по величини граду, Гумрију, представљју својеврсну гаранцију против евентуалне војне акције турских снага.

39 lbid.

${ }^{40}$ Eugene Rumer, Richard Sokolsky, Paul Stronski, U.S. Policy toward the South Caucasus: Take Three, Carnegie Endowment for International Peace, May 31, 2017, https:// carnegieendowment.org/2020/10/20/russia-s-stony-path-in-south-caucasus-pub82993, 18/02/2021.
} 
реализацију овакве врсте војне операције, којим би повратио суверенитет над отцепљеном територијом. Истовремено, овај начин савременог ратовања омогућава ангажовање релативно мањих војних формација у сукобу у коме се умањује значај и утицај морала становништва на његов исход. Употребом надмоћне борбене технике, Азербејџан је успео да превазиђе победнички дух Јермена стечен победама у сукобима деведесетих година прошлог века, уз минимално ангажовање сопственог људства и његовог излагања корона вирусу. ${ }^{41}$

Азербејџан је војну операцију припремао дуго и стрпљиво, уз обезбеђење дипломатске и политичке подршке за реализацију сопствених намера, које су се, пре свега, односиле на сузбијање утицаја Русије на догађаје које планирају. У том смислу су се на спољнополитичком плану тежишно усмерили према Турској и Кини, а не Западу/САД јер би то изазвало оштар одговор попут онога из августовског рата у Грузији. Турска је традиционално заштитник Азербејџана у међународној политици, посебно због њиховог историјског сукоба са Јерменима и сталном инсистирању на геноциду над њима с почетка 20. века. Азербејџан је извесно инсистирао да обезбеди подршку председника Ердогана и Турске vis-à-vis Русије и њеног потенцијалног мешања у сукоб. Турска је несебично подржала Азербејџан, чак и директним војним ангажовањем током операција у јесен 2020. године, али је тиме деловала и превентивно, имајући у виду већ предвидљиве намере Русије да се ангажује као сила која ће бити медијатор у преговорима и за ангажовање у мировним снагама након евентуалног потписивања примирја. Кремљу је требало готово две седмице да закаже телефонски разговор Путина и Алијева, а иницијатива Лаврова за хуманитарно примирје је готово одмах доживела неуспех на терену. Други значајан играч у регионалним пословима све више постаје и Кина, која је за овај регион заинтересована у склопу програма Појас и пут. Главни партнер Кине у региону је Азербејџан, као најмногољуднија држава у региону, са најразвијенијом економијом и природним ресурсима. Ово партнерство има упориште и у геополитичком

\footnotetext{
41 За више видети Uzi Rubin, "The Second Nagorno-Karabakh War: A Milestone in Military Affairs", Mideast Security and Policy Studies, No. 184, December 2020; James M. Dorsey, "The Caspian Sea as Battleground", Mideast Security and Policy Studies, No. 187, February 2021.
} 
контексту, иако је Кина сада главни трговински партнер и за Јерменију и Грузију. Прва земља је превише зависна од Русије, док би ближа сарадња са Грузијом додатно изазвала већ осетљиву Русију, па је Азербејџан логичан избор савезника. Кина је већ постала трећи увозник у Азербејџан, после Русије и Турске. Ова држава пружа највећи потенцијал за политичку сарадњу са Кином, која за разлику од Запада нема никаквих примедби на стање људских права у тој држави. Азербејџан се нада да ће реализација пројекта Појас и nуm обезбедити већи проток робе кроз ову државу, поготово теретног саобраћаја преко Каспијског мора и железнице која је пуштена у рад 2017. године између Бакуа и Карса у Турској и Грузије. ${ }^{42}$

Ангажман Русије и Турске, као главних регионалних актера у конфликту у Нагорно-Карабаху, резултирао је потписивањем примирја 9. новембра 2020. Председник Азербејџана Илхам Алијев, премијер Јерменије Никол Пашинијан и руски председник Владимир Путин потписали су декларацију којом је дефинисан потпуни прекид ватре, крај свих војних активности и контрола територије које су држале две стране у тренутку прекида сукоба. Иако је даљи ток ове кризе тешко у пуној мери предвидети, два сценарија су, сасвим извесно, мало вероватна. Први је потпуно гушење Нагорно-Карабаха и трајно запоседање читавог региона од стране Азербејџана. Други је остваривање међународног признања Нагорно-Карабаха као независне државе. Оба сценарија би водила ка крајњим исходима где би заинтересоване стране морале агресивније да реагују, што би довело до, у најмању руку, регионалног сукоба са великим потенцијалом за ескалацију рата на друга подручја. Зато се очекује да ће у овом простору и даље остати замрзнут конфликт, а да ће Русија и Турска на тај начин држати регион под својом подељеном контролом, без утицаја САД, што обема странама одговара.

\section{Закључна разматрања}

Амерички ангажман у овом делу евроазијске континенталне плоче, историјски посматрано, био је релативно ограничен. Прикључивањем

\footnotetext{
42 Philip Remler, Russia's Stony Path in the South Caucasus, Carnegie Endowment for International Peace, October 20, 2020, https://carnegieendowment.org/2020/10/20/ russia-s-stony-path-in-south-caucasus-pub-82993, 11/02/2021.
} 
Турске у НАТО, Сједињене Државе успеле су да се приближе Блиском истоку и Кавказу, али без могућности дубље пројекције моћи унутар Азије. Након распада Совјетског Савеза ситуација на Кавказу се драматично мења. Осим вишегодишњег рата у Чеченији, три бивше републике (Грузија, Јерменија и Азербејџан) стичу независност, што уједно мења геополитички пејзаж овог региона.

Амерички интерес на Кавказу добија нову димензију крајем другог мандата председника Буша млађег, односно 2008. године када се на иницијативу тадашњег председника Грузије Сакашвилија покреће питање интеграције Грузије у НАТО. Сакашвилијев план наишао је на оштар одговор Русије, док је, с друге стране, изостала значајнија подршка западних сила. Како би предупредила нежељене политичке промене у овом региону, Русија је августа 2008. године војно интервенисала против Грузије, чиме је у најмању руку одложена даља интеграција Грузије у НАТО. Иако је неспорно да би приступање Грузије у Алијансу обезбедило САД боље позиционирање у односу на Русију, посебно у погледу приступа меком трбуху евроазијског колоса и турбулентном региону Кавказа, Сједињене Државе нису демонстрирале одлучност у подршци НАТО политике отворених врата у случају Грузије, али нису ни одустале од наведене политике.

Уздржаност Америке поводом рата у Грузији 2008. године произилази из више аспеката. У том периоду САД је већ била оптерећена ратовима у Ираку и Авганистану, док је америчка администрација трпела велике критике због неуспелих програма обнове ових држава. Друго, у периоду 2007-2008. године свет је улазио у економску кризу која је нагло ескалирала у Америци у јесен 2008. године. Такође, исте године истицао је мандат тадашњем америчком председнику Џорџу Бушу млађем, који је током свог мандата успео да успостави релативно добре односе са Москвом. Не желећи продубљивање конфликта на Кавказу и потенцијално ширу дестабилизацију евроазијског простора, Сједињене Државе нису инсистирале на евроатлантској интеграцији Грузије. Наведени процеси утицали су на уздржаност Америке, што је довело до перцепције да је питање Грузије успех руске спољне политике и пример традиционалног уравнотежавања хегемона у 21. веку. Свакако, након Грузије остале државе региона су једно време одустале од показивања значајнијих аспирација за западне интеграције. Тај процес је на одређени 
начин постао поново уочљив након кризе у Украјини, када је ова држава напустила политику војне неутралности.

Геополитички значај Кавказа можемо сагледати у два аспеката. Прво, позиција овог простора у ширем концепту Римленда и Евроазије директно утиче на руски безбедносни интерес и концепт одбране јужних граница државе. Друго, енергетски потенцијал овог простора, као и његов значај за транзит енергената, чини Кавказ важним чиниоцем у европским и америчким геополитичким калкулацијама.

Геополитичку позицију Кавказа можемо дефинисати као мост између два стожера Римленда, тј. Украјине (источне Европе) и Блиског истока. У класичној геополитичкој теорији ова два простора сматрају се кључним за актере који покушавају да се приближе централном делу Евроазије, односно тзв. Хартленду. Стратешке концепције великих сила чак и у 21. веку умногоме следе геополитичке принципе успостављене пре више од века, због чега поједини региони и даље не губе геополитички и геостратешки значај. У том погледу потенцијално позиционирање САД на простору Кавказа омогућило би бољу контролу кључних праваца који воде у унутрашњост континента. За Сједињене Државе, као првенствено поморску силу, стицање сигурног ослонца унутар копна омогућило би дубљу пројекцију моћи ка централној Азији. То би значајно нарушило безбедносне интересе Русије, која на овај регион гледа као на своју ексклузивну зону интереса која се суштински може одредити као простор бившег СССР-а.

Енергетски значај Кавказа као транзитне зоне уско је повезан са геополитичким одређењем региона као „моста“, али овог пута између централне Азије и Европе. Наиме, допремање гаса из Азије до Европе врши се преко Русије, Кавказа (Азербејџан) и Ирана. С обзиром на затегнуте односе са Москвом и Техераном, као и тенденцијом западних држава да Русију и Иран перципирају као непријатељске елементе у међународној политици, значај енергетског коридора кроз Азербејџан и тзв. „Ганџа гап“ је од велике важности. Енергетска зависност Европе од азијских држава често је представљана као средство у рукама Кремља да контролише поједине одлуке западних земаља. Ескалацијом украјинске кризе и рата који је уследио на истоку ове државе, Америка је отпочела програм допремања течног гаса европским савезницима, али за сада то не представља одрживу алтернативу која може да покреће индустрију 
Западне Европе. Из овог разлога, обезбеђивање независности азербејџанског коридора и његово очување представља императив не само Европљанима већ и Америци, која на тај начин настоји да гарантује енергетску безбедност својим савезницима.

Сматра се да би значајније геополитичко позиционирање САД у овом региону било скопчано са многим ризицима, иако је неспоран његов значај за даљу пројекцију моћи актуелног хегемона. Амерички геостратешки интереси у овом региону детерминисани су деловањем других регионалних сила попут Русије и Турске. Кључно несагласје рускоамеричких интереса тиче се протока енергената кроз Азербејџан и настојање Русије да успостави потпуни монопол снабдевања гасом других европских држава. Други проблем са којим се Америка сусреће јесте њена глобална улога као пружаоца безбедности (енг. Security provider). 3 а разлику од САД, Русија у региону јужног Кавказа традиционално себе представља као кључног играча на кога мале државе могу да рачунају, не само у погледу снабдевања оружјем већ и као битног чиниоца стабилности регионалног поретка.

Због стратегијског опредељења Русије да је њен спољнополитички приоритет утицај на суседне државе бивше републике Совјетског Савеза, амерички ангажман на овом простору је релативно ограничен. Из тог разлога интерес САД у Нагорно-Карабаху треба сагледати у контексту ширих стратешких одређења савремене америчке спољне политике. Повлачење са глобалних фронтова, које је отпочело још у време Обамине администрације а наставило се у Трамповом мандату, не означава нужно нови изолационизам америчке политике. Последња америчка администрација није започела ниједан рат, по чему ће можда и остати упамћена. Стратегија о којој је реч усмерена је првенствено на спречавање потенцијалног пренапрезања америчке моћи, која у удаљеним регионима света наилази на све већи отпор сила у успону. Пренапрезање је иначе уско везано за концепт америчког деклинизма, који је одређен не само у односу на унутрашње капацитете државе већ зависи и од капацитета других изазивача и њиховог положаја на глобалној лествици моћи.

Како би умањила ефекте ових појава и потенцијално их преокренула, Сједињене Државе настојаће да путем других актера остваре своје амбиције у регионима који нису од виталног значаја. „Прокси“ приступ, о коме је реч, може се још представити и као „стратегија пуштања крви“, о 
којој Миршајмер дискутује у својој књизи „Трагедија политике великих сила", а која је усмерена на увлачење других играча у исцрпљујући конфликт и кризни менаџмент. Потписивањем споразума о прекиду непријатељстава и ангажовање мировних снага Русије и Турске, status quo у јужном Кавказу је „закључан“ за екстерне играче, што не значи да Сједињене Државе у будућем периоду неће имати значајнију улогу у решавању конфлитка у Нагорно-Карабаху. „Упетљавањем“ регионалних сила у контролу овог конфликта Америка, такође, себи отвара простор за обуздавање Турске и њених неоотоманских амбиција у региону ширег Блиског истока, тако да се као контрапартнер турским интересима јавља Русија. Асиметричним уравнотежавањем Сједињене Државе настојаће да регионалне играче „закључају“ у проблематику јужног Кавказа, чиме ограничавају могућност да се један од њих наметне као регионални хегемон.

У оваквом распореду регионалне равнотеже снага, реално је очекивати да ће Сједињене Државе наставити да воде политику која је препознала Грузију као стратешки ослонац за даљи продор на Кавказу. Грузија представља много мањи стратешки ризик за пројекцију дугорочних интереса од Украјине која представља далеко већи изазов, јер је Русија показала одлучност и спремност да делује муњевито и рационално током кризе у овој држави. Улазак у регионалну равнотежу снага на Кавказу је неупоредиво лакше остварити уколико то Сједињене Државе учине на „мала врата“ - преко Грузије. Сматрамо да Украјина, у овом контексту, значи превелики ризик који ће представљати наредни стратешки изазов за САД, уколико успеју да се позиционирају у регионалну равнотежу снага кроз прикључења Грузије НАТО.

\section{Литература}

Abushov, Kavus, "Russian foreign policy towards the Nagorno-Karabakh conflict: prudent geopolitics, incapacity or identity?", East European Politics, Vol. 35, Issue 1, 2019, pp. 72-92.

Agenda.Ge, Agile Spirit 2019: exercise to host over 3,000 NATO and partner troops in Georgia, https://agenda.ge/en/news/2019/391, 17/03/2021.

Agenda.Ge, NATO announces deepening partnership with Georgia, Ukraine, https://agenda.ge/en/news/2020/1028, 27/03/2021. 
Atlantic Council, End the Russian veto on Georgian accession, https://www.atlanticcouncil.org/content-series/nato20-2020/end-therussian-veto-on-georgian-accession/, 24/03/2021.

Caspian Policy, Noble Partner Military Exercise in Georgia, https://www.caspian policy.org/nato-exercises-in-georgia/, 17/03/2021.

Daly, John C. K., Russia's Discreet Satisfaction Over Georgia's Anaklia Port Debacle, Jamestown, https://jamestown.org/program/russias-discreetsatisfaction-over-georgias-anaklia-port-debacle/, 18/03/2021.

De Waal, Thomas, The Caucasus - An Introduction, Oxford University Press, 2010.

Desseyn Ryan, Tchantouridzé, Lasha "Realpolitik And The Russia-Georgia War: Three Years On", Central Asia And The Caucasus, Vol. 13, Issue 1, 2012, pp. 111-119.

Deutche Welle, Georgia launches joint military drills with NATO countries, https://www.dw.com/en/georgia-launches-joint-military-drills-with-natocountries/a-54846498, 27/03/2021.

Dorsey, James M., "The Caspian Sea as Battleground", Mideast Security and Policy Studies, No. 187, February 2021, pp. 5-15.

German, Tracey, "The Nagorno-Karabakh Conflict between Azerbaijan and Armenia: Security Issues in the Caucasus", Journal of Muslim Minority Affairs, Vol. 32, Issue 2, 2012, pp. 216-229.

Gordadze, Thornike, "Georgian-Russian Relations in the 1990s", in: The Guns of August: Russias War in Georgia (eds.) Svante E. Cornell and S. Frederik Starr, M. E. Sharpe, New York, 2009. pp. 28-49.

Hamilton, Robert E., "August 2008 and Everything after: A Ten-Year Retrospective on Russia-Georgian War", Foreign Policy Research Institute, October 2018.

Hill, Fiona, "The Real Reason Putin Supports Asad", Foreign Affairs, March 2013. Illarionov, Andrei, "The Russian Leadership's Preparation for War, 1999-2008", in: The Guns of August: Russias War in Georgia (eds.) Svante E. Cornell and S. Frederik Starr, M.E. Sharpe, New York, 2009, pp. 49-85.

Kofman, Michael, The August War, Ten Years On: A Retrospective On The RussoGeorgian War, War on the Rocks, August 2018, https://warontherocks. 
com/2018/08/the-august-war-ten-years-on-a-retrospective-on-the-russogeorgian-war/, 04/03/2021.

Lazić Jović, Ana, Jelisavac Trošić, Sanja, Jazić, Aleksandar, „Problem Nagorno Karabah u svetlu bilateralnih odnosa članica Minsk grupe OEBS-a", Međunarodni problemi, Vol. LXIII, br. 4, str. 583-612.

Lo, Bobo, Russian Foreign Policy in the Post-Soviet Era Reality, Illusion and Mythmaking, Palgrave Macmillan, UK, 2002.

NATO Backgrounder, Deepening Relations with Georgia, https://www.nato.int/ nato_static/assets/pdf/pdf_publications/deepening_relations_with_georgi a_en.pdf, 15/03/2021.

NATO, Relations with Georgia, https://www.nato.int/cps/en/natohq/topics_ 38988.htm, 04/03/2021.

NDI, NDI Poll: EU and NATO Support Remains Strong but Threatened by Russia and Perception of Harm to Culture and Values; Armenian and Azeri Communities Respond Differently to NATO Membership, https://www.ndi. org/publications/ndi-poll-eu-and-nato-support-remains-strong-threatened -russia-and-perception-harm, 13/03/2021.

Nilsson, Niklas, "Georgia's Rose Revolution: The Break with the Past", in: The Guns of August: Russias War in Georgia (eds.) Svante E. Cornell and S. Frederik Starr, M. E. Sharpe, New York, 2009, pp. 85-104.

Петровић, Драган, Анђелковић, Драгомир, Николић, Горан, Геополитика Закавказја, Институт за међународну политику и привреду, Београд, 2010.

Pallin Vendil, Carolina, Westerlund, Fredrik, "Russia's war in Georgia: lessons and consequences", Small Wars \& Insurgencies, 2009, Vol. 20, Issue 2, pp. 400-424.

Remler, Philip, Russia's Stony Path in the South Caucasus, Carnegie Endowment for International Peace, https://carnegieendowment.org/2020/10/20/ russia-s-stony-path-in-south-caucasus-pub-82993, 11/03/2021.

Remler, Philip, Russia's Stony Path in the South Caucasus, Carnegie Endowment for International Peace, October 20, 2020, https://carnegieendow ment.org/2020/10/20/russia-s-stony-path-in-south-caucasus-pub-82993, $18 / 02 / 2021$. 
Rodman, Peter W., "The Challangers of a Falling power", in: Robert Kagan and William Kristol (eds.), Present Dangers: Crisis and Opportunity in American Foreign and Defense Policy, Encounter Books, San Francisco, 2000, pp. 75-99.

Rubin, Uzi, "The Second Nagorno-Karabakh War: A Milestone in Military Affairs", Mideast Security and Policy Studies, No. 184, December 2020, pp. 5-15.

Rumer, Eugene, Sokolsky, Richard, Stronski, Paul, U.S. Policy Toward the South Caucasus: Take Three, Carnegie Endowment for International Peace, https://carnegieendowment.org/2017/05/31/u.s.-policy-toward-southcaucasus-take-three-pub-70122, 18/02/2021.

Smolnik, Franziska, "The Strategic Partnership between Georgia and the United States: Vision Wanted", German Institute for International and Security Affairs, SWP Research Paper, 15 December 2020, Berlin.

US Embassy in Georgia, Exercise Noble Partner 2020 begins, https://ge. usembassy.gov/exercise-noble-partner-2020-begins/\#: :text=Exercise\% 20Noble\%20Partner\%20is\%20designed,exercises\%2C\%20and\%20combin ed\%20mechanized\%20maneuvers, 17/03/2021.

US Embassy in Georgia, https://ge.usembassy.gov/statements-to-the-presswith-georgian-prime-minister-mamuka-bakhtadze-as-part-of-the-u-sgeorgia-strategic-partnership-commission-june-11/, 18/03/2021.

Visegrad Insight, A Staunch Ally, https://visegradinsight.eu/staunch-allygeorgia-nato/, 24/03/2021.

Welt, Cory, Georgia: Background and U.S. Policy, Congresional Research Service, https://fas.org/sgp/crs/row/R45307.pdf, 21/03/2021.

Wivel, Anders, "Living on the edge: Georgian foreign policy between the West and the rest", Third World Thematics: A TWQ Journal, Vol. 1, Issue 1, 2016, pp. 92-109.

Канцеларија НАТО у Грузији, https://www.nato.int/cps/en/natohq/ topics_81066.htm?selectedLocale=en, 11/03/2021.

Степић, Миломир, Геополитика: Идеје, теорије, концепције, Институт за политичке студије, Beograd, 2016. 


\title{
GEORGIA AS A WESTERN “TROJAN HORSE" IN THE CAUCASUS
}

\begin{abstract}
After the fall of the Soviet Union, the Caucasus proved to be a fertile ground for ethnic and religious conflicts. The former Soviet Republics, eager to protect their newly gained independence, have tried different methods in order to stabilize internal security affairs and balance out between Russian interests and their own political aspirations. After the Rose revolution, Georgia focused its foreign policy efforts towards the West, hoping that such politics would eventually help her secure its power and sovereignty over South Ossetia and Abkhazia. Georgia, as a small country, had sought out how to "cash in" its geopolitical position, providing Western powers a convenient launch pad for future operations against Russia and its interests in the "Near Abroad". However, the conflict in 2008 and the Russian intervention had made clear that the Caucasus was not for the taking. Moreover, the West has only a vague representation of the region's culture, tradition, political and security affairs as well as the regional balance of power. The recent clashes in Nagorno-Karabakh, on the one hand, have further proven the "inaccessible" nature of the region for Western powers. On the other hand, the conflict solidified the regional balance of power in which Russia and Turkey represent the main players.The following article will focus on Georgian politics and the country's relations with Russia as well as with other Western powers. Examining the Georgian foreign politics in the geopolitical context of the Caucasus, which can be described as imprudent, we will demonstrate how small countries can impact the regional balance of power.

Keywords: Georgia, Russia, West, Caucasus, Nagorno Karabakh.
\end{abstract}

